\title{
Spatio-temporal distribution of Neomegalotomus parvus (Hemiptera: Alydidae) in soybean/corn crop with beetle bank
}

Ivan Carlos Fernandes Martins ${ }^{1} \odot$, Francisco Jorge Cividanes $^{2} \odot$, José Carlos Barbosa ${ }^{\circledR} \odot$,

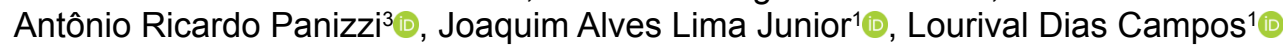

\footnotetext{
1 Universidade Federal Rural da Amazônia, Campus Capanema, Capanema, PA, Brasil. E-mail: icfmartins@yahoo.com.br; joaquim.junior@ufra.edu.br; lourivaldias@gmail.com ${ }^{2}$ Universidade Estadual Paulista Júlio de Mesquita Filho, Faculdade de Ciências Agrárias e Veterinárias de Jaboticabal, Jaboticabal, SP, Brasil. E-mail: fj.cividanes@unep.br; jc.barbosa@unesp.br

${ }^{3}$ Embrapa Trigo, Passo Fundo, RS, Brasil. E-mail: antonio.panizzi@embrapa.br
}

ABSTRACT: The true bug Neomegalotomus parvus (Westwood) is known as an insect pest of some agricultural crops. However, is limited information on the behavior and influence of environmental factors on its occurrence in the field. This study aimed to determine the population dynamics and spatial distribution of $N$. parvus in soybean and corn crops with presence of a refuge area. Conducted this study in an area with soybean/corn crop succession, and with fallow period both where there was a beetle bank, to assess the spatial distribution pattern of $N$. parvus and to link their eventual aggregation and colonization to the presence of a beetle bank. We also evaluated the influence of rainfall, air temperature and the phenological stages of the crops on the temporal distribution of this true bug. The results showed that $N$. parvus has an aggregated pattern of spatial distribution and that aggregation and colonization is related to the agricultural field but does not benefit from the presence of the beetle bank. The higher abundance of $N$. parvus occurred during the corn crop period when the grains were physiologically mature and when there was reduced rainfall and milder temperatures. These results may contribute to the development of a management plan for $N$. parvus, where actions could be directed.

Key words: aggregate distribution; phenological phases; refuge areas; true bug

\section{Distribuição espaço-temporal de Neomegalotomus parvus (Hemiptera: Alydidae) em cultivo soja/milho com área de refúgio}

RESUMO: O percevejo Neomegalotomus parvus (Westwood) é conhecido como praga de algumas culturas. No entanto, são limitadas as informações sobre o comportamento deste inseto e a influência de fatores ambientais em sua ocorrência no campo. Objetivou-se neste estudo determinar a dinâmica populacional e a distribuição espacial de N. parvus em culturas de soja e milho com presença de uma área de refúgio. $O$ estudo foi conduzido em uma área com sucessão de soja/milho, e período de pousio, onde foi implantado uma área de refúgio (beetle bank), para avaliar o padrão de distribuição espacial de N. parvus e vincular sua eventual agregação e colonização à presença da área de refúgio. Também se avaliou a influência da precipitação, temperatura do ar e os estágios fenológicos das culturas na distribuição temporal deste percevejo. Os resultados mostraram que N. parvus possui um padrão agregado de distribuição espacial e que a agregação e a colonização estão relacionadas à cultura, contudo os insetos não se beneficiam da presença da área de refúgio. A maior abundância de $N$. parvus ocorreu no período do milho, com grãos fisiologicamente maduros, chuvas reduzidas e temperaturas amenas. Esses resultados podem contribuir para o desenvolvimento de planos de manejo para N. parvus, com ações direcionadas.

Palavras-chave: distribuição agregada; fases fenológicas; áreas de refúgio; percevejo 


\section{Introduction}

A large number of phytophagous insects and other arthropods are associated with soybean and corn crops (Hartman, et al., 2015; Panizzi \& Schaefer, 2015; Sappington et al., 2018). Species of the order Hemiptera are abundant in agricultural fields, with species of the families Alydidae, Cydnidae and Pentatomidae classified as notable pests of soybean (Grazia et al., 2015; Panizzi \& Schaefer, 2015; Schwertner \& Nardi, 2015). Due to the damage that the species Neomegalotomus parvus (Westwood) (Alydidae) may cause to soybean crops, it is considered a significant pest for this crop (Schaefer \& Ahmad, 2008; Panizzi \& Schaefer, 2015), and it is not known action of this insect in the corn crop.

The creation of refuge areas in the field margins and beetle banks between the crops can benefit the diversity and occurrence of natural enemies, and this technique is easily implemented in integrated pest management programs (Collins et al., 2003). However, the creation of refuge areas can also promote the occurrence and persistence of insect pests. The manipulation of agroecosystems accomplished without studies, can attract not only natural enemies as well as phytophagous insects (Philpott, 2013). Therefore, it is necessary to study the effect of environmental manipulation of all groups of insects.

Creating areas of refuge in agroecosystems aimed at pest management requires an ecological understanding of insect herbivores and natural enemies and knowledge of insect/ plant interactions (Philpott, 2013). Therefore, it is necessary to expand the knowledge of the behavior of insects in the field.

This study aimed to determine the population dynamics and spatial distribution of $N$. parvus in soybean and corn crops and to analyze the influence of the phenological phases of cultivated plants, the meteorological factors and the presence of a refuge area on the occurrence of this insect.

\section{Materials and Methods}

This study was conducted in a $100 \times 100 \mathrm{~m}$ area located on 10 ha of land that belongs to the Faculdade de Ciências Agrárias e Veterinárias (FCAV), Universidade Estadual Paulista (UNESP), Jaboticabal, SP, Brazil (latitude: $21^{\circ} 15^{\prime} 29^{\prime \prime} \mathrm{S}$ and longitude: $48^{\circ} 16^{\prime} 54^{\prime \prime} \mathrm{W}$ ).

The experimental area was planted with soybean in 2008 2009 and 2009-2010 and with corn in winter of the 2009. The area was left fallow after soybean harvest in 2010 . Insecticides were not applied in this area, but each soybean crop received two fungicide and herbicide applications between January and February. In 2008-2009, soybean crops were sown on $12 / 05 / 2008$ and harvested on $03 / 27 / 2009$; in 2009-2010, soybean crops were sown on 12/17/2009 and harvested on $04 / 12 / 2010$. Corn was sown on 03/04/2009 and harvested on 09/25/2009.

A refuge area (beetle bank) was created on an $80 \mathrm{~m}$-long, 2 $\mathrm{m}$-wide, and $40 \mathrm{~cm}$-high space at the center of the agricultural area, according to the methodology of (Collins et al., 2003). This bank did not extend to any of the field boundaries but formed an "island" in the middle of the field (Figure 1).

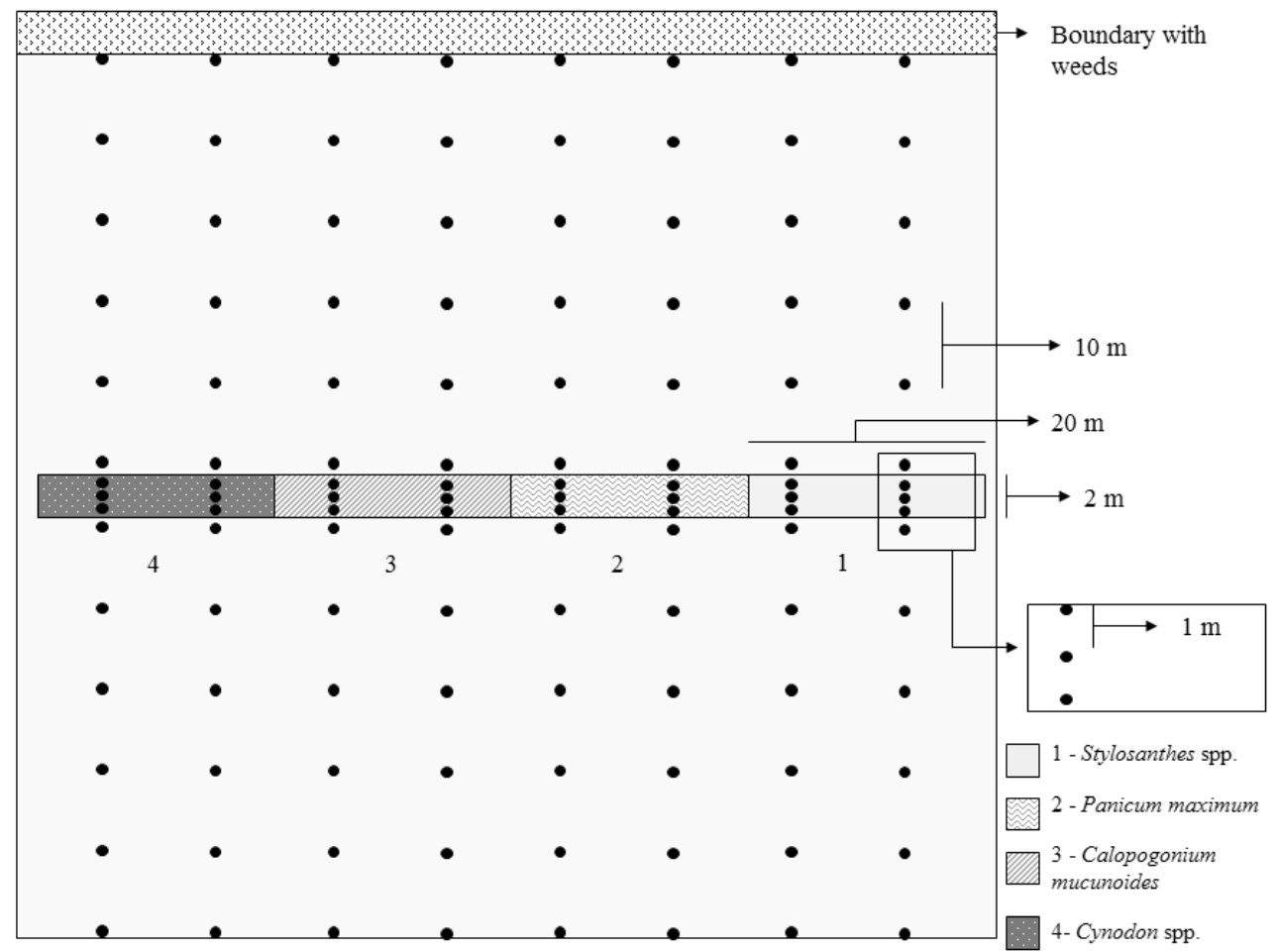

Figure 1. Design of the experimental area showing the position of the refuge area (central bar), the blocks with different tonality and accompanied by the numbers corresponds to the position of each treatment. Dots represent the locations of traps. The central refuge area was surrounded by a crop of soybean (season: 2008/09 and 2009/10) or corn (offseason: 2009) or was fallow (offseason: 2010). 
This beetle bank was divided into four $20 \mathrm{~m}$ plots cultivated with the following perennial herbaceous plant types: Panicum maximum 'Massai', Cynodon spp. 'Tifton 85', Stylosanthes spp. 'BRS Campo Grande', and Calopogonium mucunoides 'Common' (Figure 1). Several characteristics were considered in selecting herbaceous plants for the refuge areas, such as rapid growth, resistance to adverse conditions of humidity and temperature, low need for cultivation, durability and a reduced potential of becoming weeds (MacLeod et al., 2004).

Neomegalotomus parvus were collected using pitfall traps $(500 \mathrm{~mL})$ containing a mixture of water $(150 \mathrm{~mL})$, formaldehyde (1\%) and drops of neutral detergent. This technique is used to capture any insects which may be associated with soil, definitely (insects that have every cycle in soil) or temporary (insects with part of the life cycle on the ground or to use this shelter or foraging). The pitfall traps were made of a plastic cup (80 $\mathrm{mm}$ diameter $\times 140 \mathrm{~mm}$ high) set in another plastic cup with holes in the base to drain the rainwater. Each trap was covered with a plastic roof (15 cm diameter) three $\mathrm{cm}$ above the trap. The sampling was conducted fortnightly during the season and monthly in the off-season, from December $17^{\text {th }}, 2008$ to June $9^{\text {th }}, 2010$, for a total of 27 (n) sampling dates. The traps were kept in the field for one week then removed and taken to the laboratory to screen, assemble and identify the hemipterans.

For each block of herbaceous plants, six traps (separated by $1 \mathrm{~m}$ ) were installed, distributed in two parallel rows of three traps, spaced $10 \mathrm{~m}$ from each other (Figure 1). In the field, the traps were installed according to the distribution grid. The first traps were one meter from the block of herbaceous plants within the refuge, and the others were installed every $10 \mathrm{~m}$ in the surrounding crop (Figure 1). The confidence interval was used to compare means of $N$. parvus in different areas, for it was calculated the number of insects collected by traps in each area (mean number) of this amount was calculated the mean (mean number / $\mathrm{n}$ ).

To study the population fluctuation, the total number of specimens of the $N$. parvus found in all the traps during the sampling period was considered. The influence of meteorological factors was evaluated using multiple regression analysis with variable selection by the "stepwise" method, which considered the $10 \%$ level of significance for the inclusion of independent variables (temperature and rainfall). The meteorological factors considered included the maximum and minimum temperatures $\left({ }^{\circ} \mathrm{C}\right)$ and rainfall $(\mathrm{mm})$. Meteorological data were obtained from agrometeorological observations conducted at FCAV/UNESP. When analyzing meteorological factors, we considered weekly mean temperatures and weekly sum of pluvial precipitation, which were always checked 7 days prior to sampling.

The phenological phases of the soybeans and corn crops were determined on the same date that the $N$. parvus insects were collected. The dominant phenological phases near each trap were determined visually. For this, we used the activity index (or percentage of individuals), noting the presence or absence of phenophase in the individuals. This method is a quantitative analysis at the population level and determines the percentage of individuals in the population of plants that expressed a particular phenological event. The phenological phases of the soybeans were assessed in accordance with the description of Sediyama et al. (2015) and the phases of the corn were assessed according to the description of Borém et al. (2017).

Several dispersion or aggregation indices are used to measure the spatial disposition of insects. They are used to determine the degree of randomness of the spatial arrangements, and their application is essential in ecological studies (Green, 1966). However, Rabinovich (1980) reported that there is no perfect index that satisfies all the desired conditions. It is therefore necessary to analyze data using several indexes.

To specify the spatial distribution of $N$. parvus, calculations were performed to determine the mean $(\mathrm{m})$, variance $\left(\mathrm{s}^{2}\right)$ and the following dispersion indices: variance/mean (Rabinovich, 1980), Morisita index, Green's coefficient (Green, 1966) and $\mathrm{K}$ exponent of negative binomial distribution. The departure from randomness was tested using the chi-square test for variance/mean, Morisita index and Green's coefficient. The data were also tested for a Poisson distribution and negative binomial distribution.

To illustrate and verify the aggregation and spatial distribution, maps of linear interpolation were used. We determined the values of the observed frequency at the sampling points and the interpolation between points. Surfer 11.0 for Windows software licensed (Golden Software Inc., 2012) was used to plot the interpolation maps.

\section{Results and Discussion}

A total of 3,129 specimens of $N$. parvus were collected throughout the sampling period, of which 2,843 (90.86\%) specimens were collected from the soybean and corn plots and only 286 specimens were collected in the refuge area (Table 1). The plots of the legumes C. mucunoides and

Table 1. Neomegalotomus parvus specimens sampled in the experimental area. Jaboticabal, SP - Brazil, 2008,2009 and 2010. $(\%=$ Percent of the total of specimens; Mean number = number of specimens / number of traps; Mean = Mean number / $n$; Confidence Interval, lower and higher).

\begin{tabular}{lccccc}
\hline \multicolumn{1}{c}{ Sampling area } & Number of specimens & $\%$ & Mean number & Mean & Confidence interval \\
\hline Cultivated area & 2,843 & 90.86 & 29.62 & 1.10 & $0.61 ; 1.55$ \\
Stylosanthes spp. & 117 & 3.74 & 19.50 & 0.72 & $0.24 ; 1.22$ \\
Calopogonium mucunoides & 83 & 2.65 & 13.83 & 0.51 & $0.21 ; 0.82$ \\
Panicum maximum & 64 & 2.05 & 10.67 & 0.40 & $0.06 ; 0.75$ \\
Cynodon spp. & 22 & 0.70 & 3.66 & 0.14 & $0.04 ; 0.25$ \\
Total & 3,129 & 100 & & & \\
\hline
\end{tabular}


Stylosanthes spp. had a larger number of specimens, 83 and 117 , respectively, when compared with the plots of the grasses Cynodon spp. and P. maximum (Table 1). However, analysis of the means demonstrated that only Stylosanthes spp. presented occurrence of $N$. parvus high similar to that found in the cultivated area. Panizzi \& Schaefer (2015) reported that $N$. parvus is associated with soybean cultivation, mainly at the maturation stage. This fact may explain the greater occurrence of this true bug in the agricultural area and when it occurred in the refuge area, preferred the areas with legumes.

The population fluctuation of $N$. parvus demonstrated that the specie was present during almost the entire study period, being absent in only three of the 27 samplings conducted. It was observed that periods of low or no rainfall and minimum or mild temperature were frequently followed by a high population. The higher population peaks occurred on September $8^{\text {th }} 2009$, in a period of low rainfall and minimum temperature (below $18{ }^{\circ} \mathrm{C}$ ) (Figure 2). Dry periods may favor increased populations of insect pests, Ewald et al. (2015) report in a long-term study in cereal area that temperature and elevation of dry years favor the occurrence of insect pests.

The influence of the meteorological factors may be confirmed by multiple regression analysis, which showed a significant negative regression coefficient for minimum temperature and rainfall (Table 2). This result explains the $35.56 \%$ population variation found, i.e., the period of low rainfall and minimum air temperature tended to increase the population density of this species. The development of the $N$. parvus population is favored in regions with a milder winter (Ventura \& Panizzi, 2003).

The species $N$. parvus is considered a pest with the potential to cause damage to the soybean crop (Panizzi \& Schaefer, 2015). However, in this study, the population peak occurred on September $8^{\text {th }} 2009$, at the end of the corn season, near the harvesting period when the grains were physiologically mature (stage E10) (Figure 3). These results
Table 2. Coefficient multiple regression analysis of Neomegalotomus parvus for meteorological factors considered: maximum and minimum temperatures $\left({ }^{\circ} \mathrm{C}\right)$ and rainfall (mm). Jaboticabal, SP - Brazil, 2008, 2009 and 2010.

\begin{tabular}{lccc}
\hline \multicolumn{1}{c}{ Variable } & $\begin{array}{c}\text { Parameter } \\
\text { estimate }\end{array}$ & $\begin{array}{c}\mathbf{F} \\
\text { value }\end{array}$ & p value \\
\hline Maximum Temperature & - & - & - \\
Minimum Temperature & -19.5817 & 4.53 & 0.0438 \\
Rainfall & -1.3030 & 3.40 & 0.0777 \\
Intercept & 518.7208 & 10.57 & 0.0034 \\
\hline \multicolumn{1}{c}{ Model } & & & \\
\hline P > F & 0.0051 & & \\
F Value & 6.62 & & \\
R-Square & 0.3556 & & \\
\hline
\end{tabular}

Considered the $10 \%$ level of significance for the inclusion of independent variables.

showed that $N$. parvus could also use the corn crop to develop and feed themselves, as well as benefit from the fallow period for shelter. Corrêa-Ferreira \& Panizzi (1999) reported that after soybean harvest, true bug species may use other crops or weeds as well as crop residues for their development and take shelter during unfavorable periods.

Population growth and peaks of growth occurred when the corn grain was fruiting and ripening so the beneficial relationship between $N$. parvus and these phenological stages may be an indication of food preference. Another hypothesis that could explain the higher population during the corn crop and fallow periods may be related to the minimum temperature and decrease in rainfall that occurred during these periods. However, because pitfall traps were used for sampling, the high occurrence at the end of the corn crop and fallow periods may indicate that this species had moved to the ground to take shelter during this period of unfavorable environmental conditions. However, some bedbugs may alter the niche or crop in an intense multiple cropping system (Smaniotto \& Panizzi, 2015).

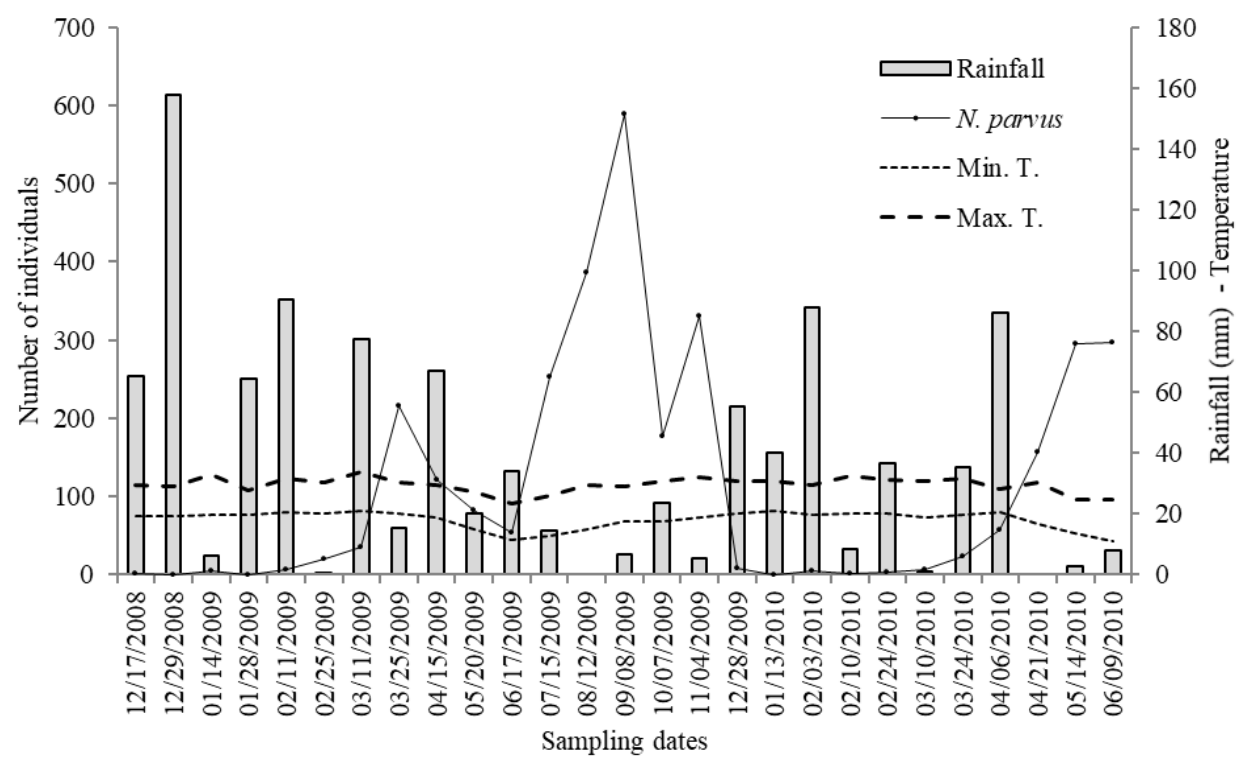

Figure 2. Population fluctuation of Neomegalotomus parvus, rainfall and maximum and minimum temperatures during the entire sampling period, Jaboticabal, SP - Brazil. 


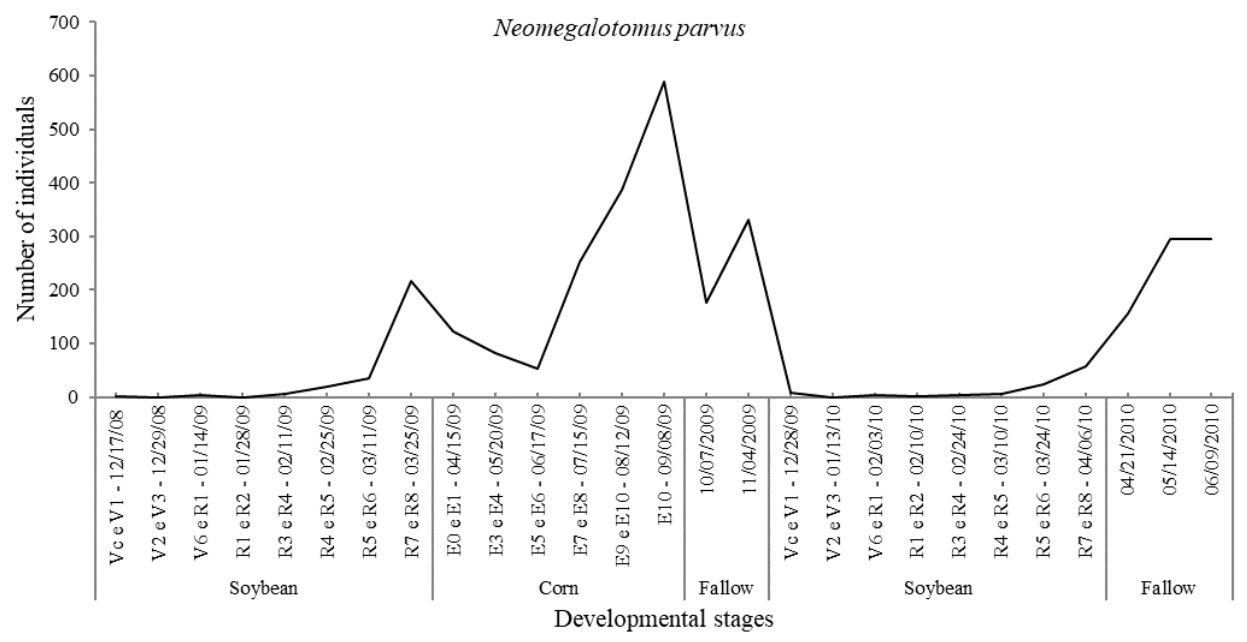

Figure 3. Population fluctuation of Neomegalotomus parvus in relation to the developmental stages of the soybean and corn crop and the fallow period, Jaboticabal, SP - Brazil. Soybean phenological stages: vegetative = Vc-V6; flowering = R1 and R2; fruiting $=\mathrm{R} 3-\mathrm{R} 6$; and maturation $=\mathrm{R} 7$ and R8. Corn phenological stages: germination $=\mathrm{E} 0$; vegetative $=\mathrm{E} 1-\mathrm{E} 3 ;$ flowering $=\mathrm{E} 4$ and $\mathrm{E} 5$; fruiting $=\mathrm{E} 6-\mathrm{E} 8$; and maturation $=\mathrm{E} 9$ and $\mathrm{E} 10$.

The spatial distribution data for $N$. parvus on most sampling dates, but especially during the periods of population peaks, yielded values that, when presented in relation to the variance/means (I) and the Morisita index (Iס) were greater than unity, indicating a clustered distribution. The results obtained using a chi-squared test for the variance/means (I), Morisita index and Green's coefficient indicated a departure from randomness on the dates of the highest incidence of $N$. parvus (significant at $5 \%$ probability), but on the other dates, randomness was not rejected (Table 3).
The Green coefficient $(\mathrm{Cx})$ showed low values greater than zero, and the values obtained for the parameter $k$ of the negative binomial distribution, estimated by the method of moments ( $\mathrm{kmom})$, were positive and less than two, confirming the aggregate distribution and indicating a high level of aggregation of this true bug (Table 3 ). This aggregation behavior was also verified by Ventura \& Panizzi (2003), who, using the Morisita index, found gregariou habit for this species that was linked to food preference and pheromones.

Initially, the adjustment of the data was tested using a probabilistic model of the Poisson distribution; however,

Table 3. Means, variances and dispersion indices for the occurrence of Neomegalotomus parvus throughout the sampling period. Jaboticabal, SP - Brazil.

\begin{tabular}{|c|c|c|c|c|c|c|c|c|c|c|c|c|c|c|}
\hline Indices & 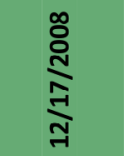 & 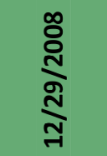 & 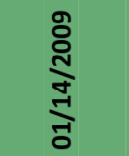 & 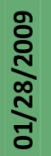 & 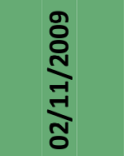 & 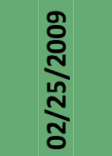 & 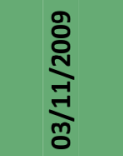 & 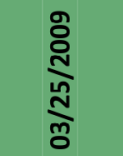 & 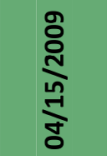 & 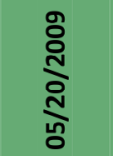 & 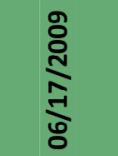 & 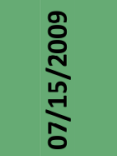 & $\frac{\text { ò }}{\text { సે }}$ & 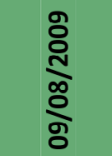 \\
\hline & \multicolumn{8}{|c|}{ Soybean crop } & \multicolumn{6}{|c|}{ Corn crop } \\
\hline$m$ & 0.0167 & - & 0.0417 & - & 0.0583 & 0.1667 & 0.3250 & 1.9750 & 1.0500 & 0.6917 & 0.4417 & 2.3000 & 3.5083 & 5.1750 \\
\hline$s^{2}$ & 0.0165 & - & 0.0571 & - & 0.0554 & 0.2073 & 0.5237 & 7.5708 & 1.9975 & 1.9125 & 0.8201 & 19.2538 & 25.1428 & 62.1960 \\
\hline $\mathrm{X}^{2} \mathrm{I} ; \mathrm{I}_{\delta}$ & $118.00^{\mathrm{NS}}$ & - & $163.00^{\mathrm{NS}}$ & - & $113.00^{\mathrm{NS}}$ & $148.00^{*}$ & $196.81^{*}$ & $1272.28^{*}$ & $235.84^{*}$ & $329.05^{*}$ & $1091.00^{*}$ & $1032.41^{*}$ & $6775.57^{*}$ & $1430.26^{*}$ \\
\hline $\mathrm{K}$ mom & -1.9833 & - & 0.1127 & - & -1.1569 & 0.6839 & 0.5315 & 0.6971 & 1.1636 & 0.3919 & 0.5155 & 0.3120 & 0.5689 & 0.4697 \\
\hline$C x$ & $-0.0084^{\mathrm{NS}}$ & - & $0.0924^{\mathrm{NS}}$ & - & $-0.0084^{\mathrm{NS}}$ & $0.0128^{*}$ & $0.0161^{*}$ & $0.0120^{*}$ & $0.0072^{*}$ & $0.0215^{*}$ & $0.0165^{*}$ & $0.0268^{*}$ & $0.0147^{*}$ & $0.0178^{*}$ \\
\hline & 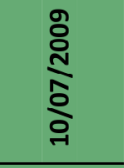 & 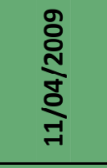 & 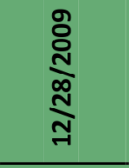 & 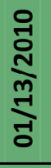 & 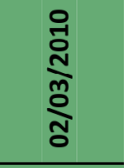 & 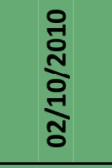 & $\begin{array}{l}\text { 엉 } \\
\text { d } \\
\text { d } \\
\text { ন্ঠ } \\
\end{array}$ & 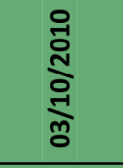 & 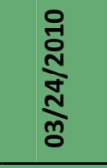 & 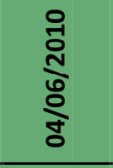 & $\begin{array}{l}\text { 웜 } \\
\text { d } \\
\text { ন } \\
\text { ㄱ } \\
\end{array}$ & 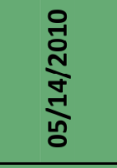 & 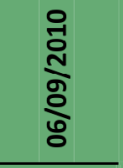 & \\
\hline $\mathrm{I}=\mathrm{s}^{2} / \mathrm{m}$ & 5.8052 & 4,3878 & 0.9412 & - & 0.9748 & 1.0000 & 0.9832 & 0.9580 & 1.9832 & 2.6031 & 3.0588 & 4.2171 & 8.1960 & \\
\hline$I_{\delta}$ & 4.1988 & 2.1467 & 0.0000 & - & 0.0000 & 0.0000 & 0.0000 & 0.0000 & 6.6403 & 3.5338 & 2.5806 & 2.3023 & 3.9111 & \\
\hline$X^{2} I ; I_{\delta}$ & $694.78^{*}$ & $535.24^{*}$ & $112.00^{\mathrm{NS}}$ & - & $116.00^{\text {NS }}$ & $119.00^{\text {NS }}$ & $117.00^{\text {NS }}$ & $114.00^{*}$ & $248.73^{*}$ & $281.17^{*}$ & $364.00^{*}$ & $503.18^{*}$ & $980.69^{*}$ & \\
\hline $\mathrm{K}$ mom & 0.3139 & 0.8954 & -1.1333 & - & -1.3222 & - & -1.4875 & -1.1900 & 0.2034 & 0.3379 & 0.6314 & 0.7667 & 0.3439 & \\
\hline $\mathrm{Cx}$ & $0.0267^{*}$ & $0.0093^{*}$ & $-0.0084^{\mathrm{NS}}$ & - & $-0.0084^{\mathrm{NS}}$ & - & $-0.0084^{\mathrm{NS}}$ & $-0.0084^{\mathrm{NS}}$ & $0.0427^{*}$ & $0.0250^{*}$ & $0.0133^{*}$ & $0.0109^{*}$ & $0.0243^{*}$ & \\
\hline
\end{tabular}

$\mathrm{m}=$ sample mean; $\mathrm{s}^{2}=$ variance; $\mathrm{I}=$ variance/mean; $\mathrm{I}_{\mathrm{s}}=$ Morisita index; $\mathrm{X}^{2} \mathrm{I} ; \mathrm{I}=$ chi-squared test of adherence to the values calculated for the variance/mean and Morisita index; $\mathrm{k}$ mom $=\mathrm{k}$ calculated by the method of moments; $\mathrm{Cx}=$ coefficient of Green. ${ }^{*}=$ Significant at $5 \%$ probability; NS $=$ not significant at $5 \%$ probability. 
because the means were lower than the variances on the dates of greater abundance of $N$. parvus (Table 3 ), the negative binomial distribution model was tested.

In the sixteen evaluations in which the degrees of freedom were sufficient for analysis, the majority of the chi-squared values was significant $5 \%$ probability for the adjustment of the Poisson distribution and was not significant for only one date, demonstrating that most of the evaluation was not randomly distributed (Table 4). Considering the negative binomial distribution, the values were not significant in ten evaluations in which there were sufficient degrees of freedom, confirming the clustered distribution of $N$. parvus (Table 4). The results presented for adjustment of the samplings to the analysis using the probabilistic models demonstrated that they are in accordance with the indices tested for this true bug.

The samples that were adjusted to the probabilistic models of spatial distribution were used to obtain maps of linear interpolation, which provided visualization of the distribution of clusters of $N$. parvus, determined by the dispersion index and adjustment to the negative binomial distribution model (Figures 4, 5 and 6).

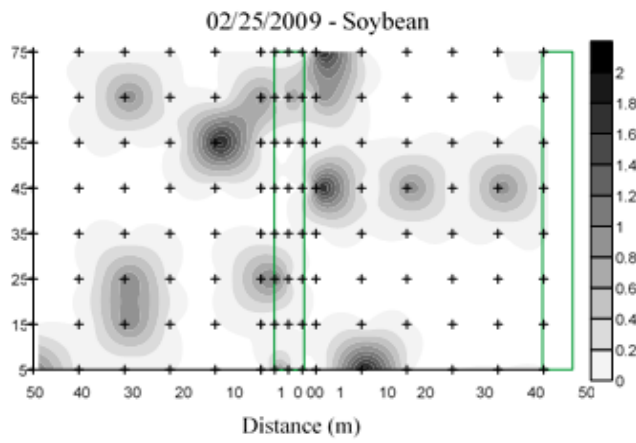

$03 / 25 / 2009$ - Soybean

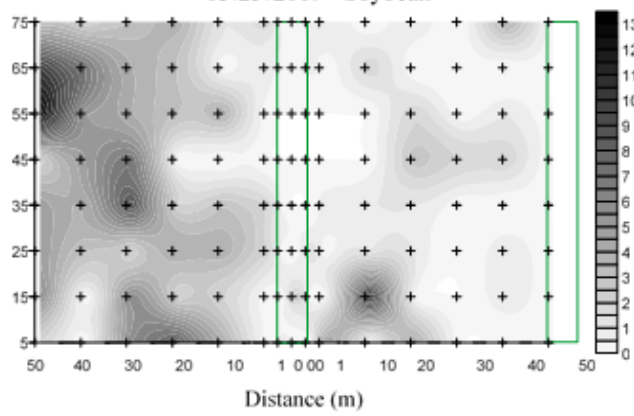

05/20/2009 - Corn

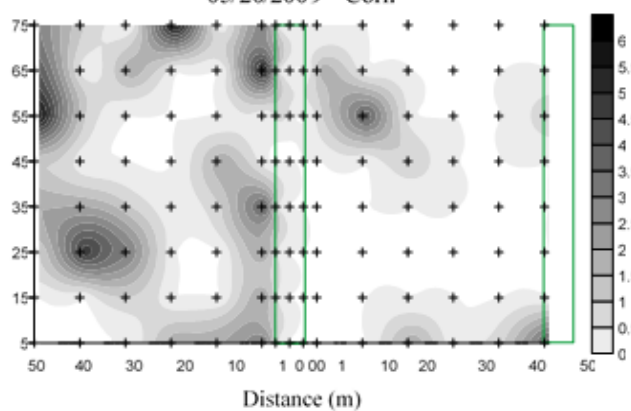

Table 4. Results obtained using a chi-squared test to adjust the Poisson and negative binomial distribution data of adult Neomegalotomus parvus. Jaboticabal, SP- Brazil.

\begin{tabular}{ccccccc}
\hline \multirow{2}{*}{ Dates } & \multicolumn{3}{c}{ Poisson } & \multicolumn{3}{c}{ Binomial negative } \\
\cline { 2 - 7 } & $\mathbf{X}^{2}$ & $\mathbf{d f}$ & $\mathbf{p}$ & $\mathbf{X}^{2}$ & $\mathbf{d f}$ & $\mathbf{p}$ \\
\hline $25 / 02 / 2009$ & $6.25^{*}$ & 1 & 0.0125 & IDF & IDF & IDF \\
$11 / 03 / 2009$ & $3.71^{\text {ns }}$ & 1 & 0.0542 & $1.23^{\text {ns }}$ & 1 & 0.2667 \\
\hline $25 / 03 / 2009$ & $128.02^{*}$ & 5 & 0.0000 & $14.18^{\text {ns }}$ & 8 & 0.0772 \\
\hline $15 / 04 / 2009$ & $48.65^{*}$ & 3 & 0.0000 & $15.32^{*}$ & 3 & 0.0016 \\
\hline $20 / 05 / 2009$ & $33.53^{*}$ & 1 & 0.0000 & $5.50^{\text {ns }}$ & 4 & 0.2400 \\
$17 / 06 / 2009$ & $13.77^{*}$ & 2 & 0.0010 & $1.23^{\text {ns }}$ & 2 & 0.5397 \\
$15 / 07 / 2009$ & $238.01^{*}$ & 6 & 0.0000 & $10.02^{\text {ns }}$ & 9 & 0.4388 \\
$12 / 08 / 2009$ & $494.28^{*}$ & 8 & 0.0000 & $9.51^{\text {ns }}$ & 12 & 0.6590 \\
$08 / 09 / 2009$ & $345.26^{*}$ & 9 & 0.0000 & $45.85^{*}$ & 15 & 0.0001 \\
$07 / 10 / 2009$ & $81.51^{*}$ & 4 & 0.0000 & $8.10^{\text {ns }}$ & 7 & 0.3236 \\
$04 / 11 / 2009$ & $377.68^{*}$ & 7 & 0.0000 & $21.70^{*}$ & 11 & 0.0268 \\
\hline $24 / 03 / 2010$ & $5.21^{*}$ & 1 & 0.0225 & $0.45^{\text {ns }}$ & 1 & 0.5040 \\
$06 / 04 / 2010$ & $22.22^{*}$ & 2 & 0.0000 & $1.91^{\text {ns }}$ & 3 & 0.5915 \\
\hline $21 / 04 / 2010$ & $42.99^{*}$ & 4 & 0.0000 & $5.83^{\text {ns }}$ & 6 & 0.4427 \\
$14 / 05 / 2010$ & $237.49^{*}$ & 6 & 0.0000 & $34.24^{*}$ & 8 & 0.0000 \\
\hline$x^{2}=5 t$
\end{tabular}

$\mathrm{X}^{2}=$ Statistics of the chi-squared test; $\mathrm{df}$. = number of degrees of freedom of the chisquared test; $p=$ probability level of the chi-squared test; ${ }^{*}$ Significant at $5 \%$ probability;

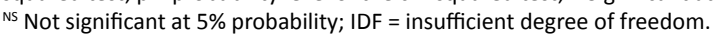

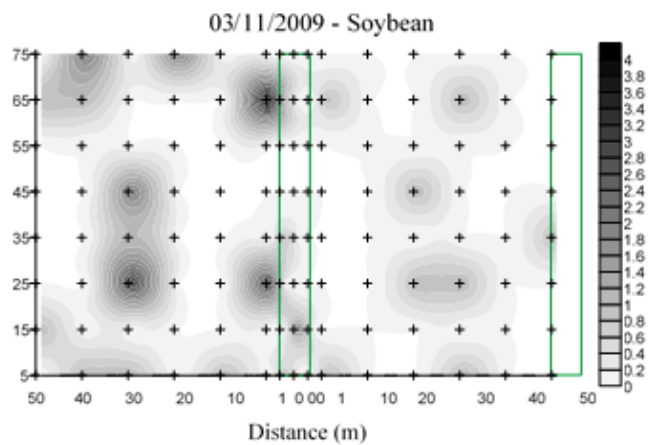

$04 / 15 / 2009-$ Corn

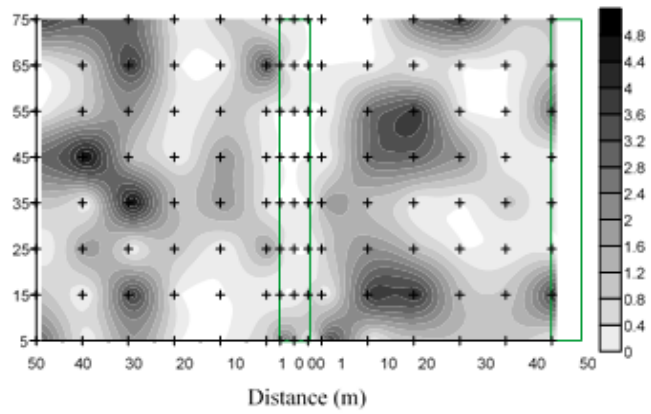

06/17/2009 - Corn

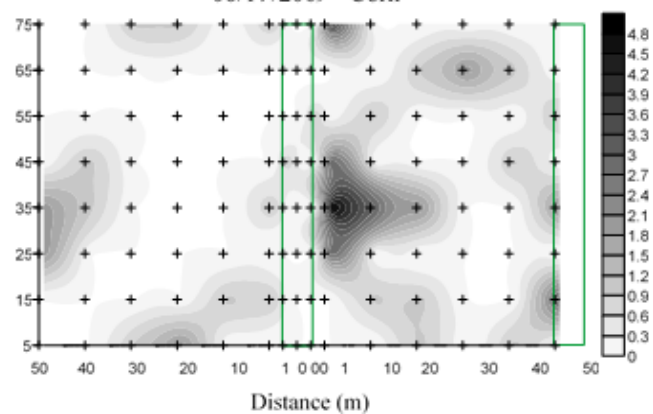

Figure 4. Maps of linear interpolation of Neomegalotomus parvus adults during the periods when there was an adjustment to the models of spatial distribution. The area delimited and the zero distance correspond to the refuge area; the area delimited on the right is the border of the cultivated area, and the + sign corresponds to the position of the traps in the soil; darkening indicates a higher density of insects. Jaboticabal, SP - Brazil. 

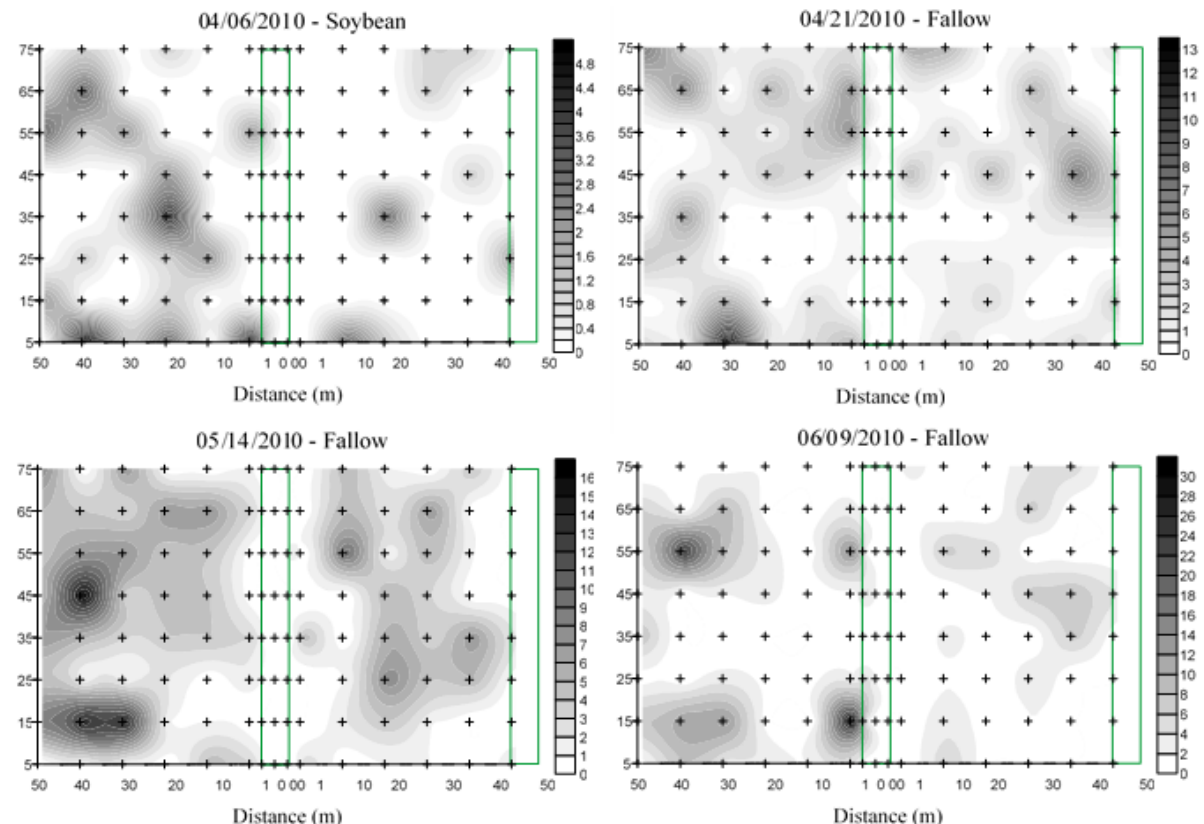

Figure 5. Maps of linear interpolation of Neomegalotomus parvus adults during periods when there was an adjustment to the models of spatial distribution. The area delimited and the zero distance correspond to the refuge area; the area delimited on the right is the border of the cultivated area, and the + sign corresponds to the position of the traps in the soil; darkening indicates a higher density of insects. Jaboticabal, SP - Brazil.
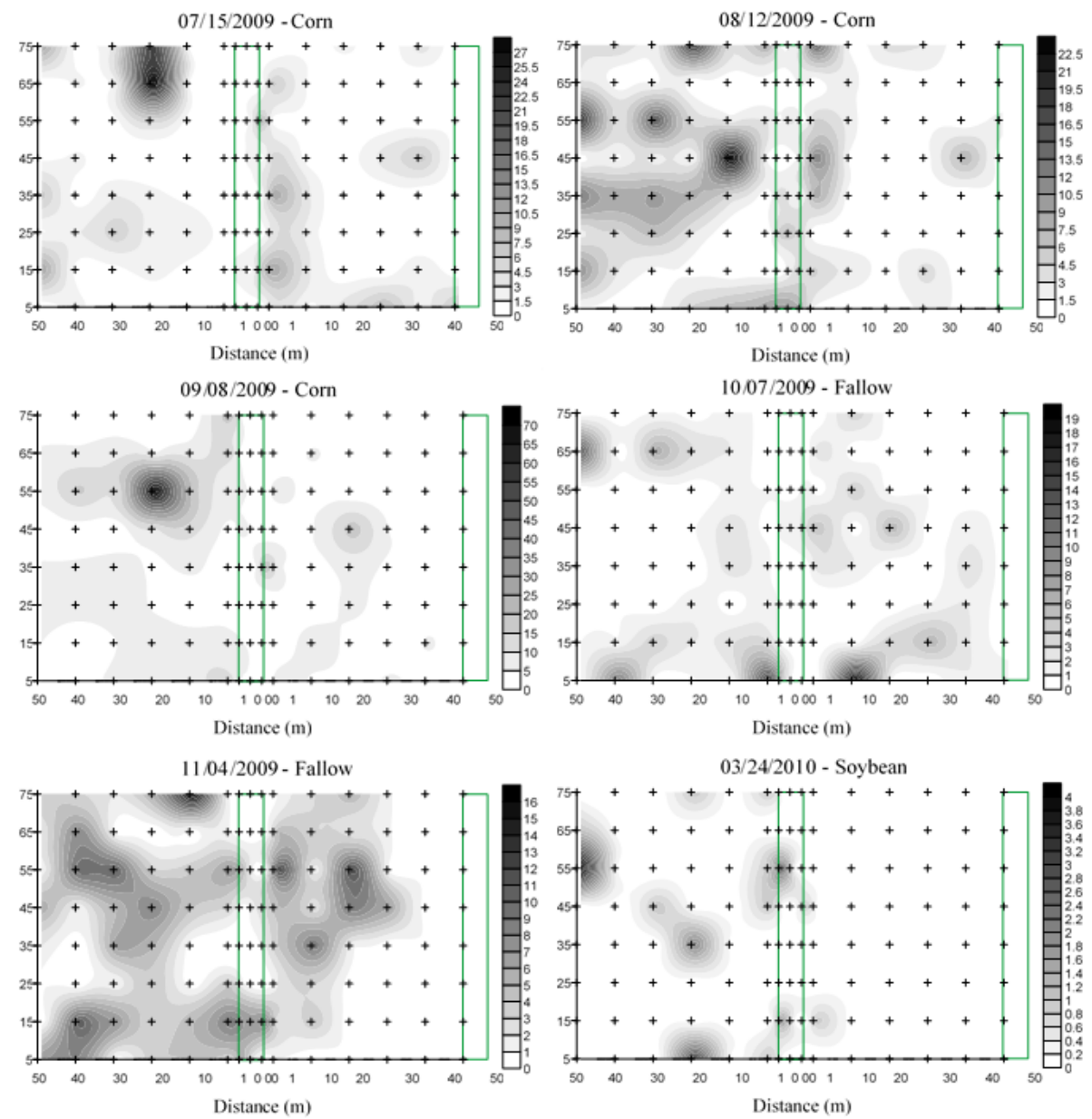

Figure 6. Maps of linear interpolation of Neomegalotomus parvus adults during periods when there was an adjustment to the models of spatial distribution. The area delimited and the zero distance correspond to the refuge area; the area delimited on the right is the border of the cultivated area, and the + sign corresponds to the position of the traps in the soil; darkening indicates a higher density of insects. Jaboticabal, SP - Brazil. 
Although the refuge areas and natural shelter may increase abundance of natural enemies and herbivorous pests (Gontijo, 2019), this study demonstrated that most of the aggregation points of $N$. parvus occurred in the agricultural field (Figures 4, 5 and 6). The observation of the aggregation points, which almost always occur, in the agricultural field supports the hypothesis that this specie presented preference of concentration in these areas and not in the refuge areas.

After the fallow period and prior to the soybean crop period of 2009/10 (Figure 5), aggregation of N. parvus in the refuge area was observed on plots where Stylosanthes spp. and $C$. mucunoides occurred. These individuals could be responsible in part for the colonization that occurred in the soybean period, but this behavior was not repeated in the subsequent fallow period, although aggregation remained in the agricultural field during this period. These results describing the population fluctuation and influence of meteorological factors and phenological phases, as well as the clustered distributions of $N$. parvus, may contribute to a management plan for this phytophagous Hemiptera, where actions could be directed.

\section{Conclusions}

The spatial distribution of Neomegalotomus parvus occurs on an aggregate basis, preferably in an agricultural field, being the refuge area has not benefited aggregation in the field.

The fluctuation of the population is influenced by meteorological factors, such as minimum temperature and rainfall, and by the phenological stage, preferring soybeans and corn at physiological maturity.

The occurrence of a fallow period may also positively influence the occurrence of $N$. parvus, this species move to the ground to take shelter during period of unfavorable environmental conditions.

\section{Acknowledgments}

We thank Alex Antonio Ribeiro and José de Souza Altamiro of the Departamento de Fitossanidade of the Universidade Estadual Paulista (UNESP) in Jaboticabal, SP for helping to develop this study. We are grateful to the Fundação de Amparo à Pesquisa do Estado de São Paulo (FAPESP) for providing the Ph.D. scholarship granted to the first author.

\section{Literature Cited}

Borém, A.; Galvão, J.C.C.; Pimentel, M.A. Milho do plantio à colheita. Viçosa: Editora UFV, 2017. 382p.

Collins, K.L.; Boatman, N.D.; Wilcox, A.; Holland, J.M. A 5-year comparison of overwintering polyphagous predator densities within a beetle bank and two conventional hedgebanks. Annals of Applied Biology, v. 143, n. 1, p. 63-71, 2003. https://doi. org/10.1111/j.1744-7348.2003.tb00270.x.
Corrêa-Ferreira, B.S.; Panizzi, A.R. Percevejos da soja e seu manejo. Londrina: Embrapa-CNPSo, 1999. 45p. (Embrapa-CNPSo. Circular Técnica, 24). http://ainfo.cnptia.embrapa.br/digital/bitstream/ CNPSO/16788/1/circTec24.pdf. 12 Out. 2018.

Ewald, J.A.; Wheatley, C.J.; Aebischer, N.J.; Moreby, S.J.; Duffield, S.J.; Crick, H.Q.; Morecroft, M.B. Influences of extreme weather, climate and pesticide use on invertebrates in cereal fields over 42 years. Global Change Biology, v. 21, n. 11, p. 3931-3950, 2015. https://doi.org/doi:10.1111/gcb.13026.

Golden Software. Surfer 11.0 for Windows. Golden: Golden Software, 2012.

Gontijo, L.M. Engineering natural enemy shelters to enhance conservation biological control in field crops. Biological Control, v. 130, p. 155-163, 2019. https://doi.org/10.1016/j. biocontrol.2018.10.014.

Grazia, J.; Panizzi, A.R.; Greve, C.; Schwertner, C.F.; Campos, L.A.; Garbelotto, T. de A.; Fernandes, J.A.M. Stink bugs (Pentatomidae). In: Panizzi A.; Grazia J. (Eds.) True bugs (Heteroptera) of the Neotropics. Entomology in Focus 2. Dordrecht: Springer, 2015. Chap 22, p. 681-756. https://doi.org/10.1007/978-94-017-98617_22.

Green, R.H. Measurement of non-randomness in spatial distributions. Researches on Population Ecology, v. 8, n. 1, p. 1-7, 1966. https:// doi.org/10.1007/BF02524740.

Hartman, G.L.; Bowen, C.R.; Haudenshield, J.S.; Fox, C.M.; Cary, T.R.; Diers, B.W. Evaluation of disease and pest damage on soybean cultivars released from 1923 through 2008 under field conditions in central Illinois. Agronomy Journal, v. 107, n. 6, p. 2373-2380, 2015. https://doi.org/10.2134/agronj15.0075.

MacLeod, A.; Wratten, S.D.; Sotherton, N.W.; Thomas, M.B. 'Beetle banks' as refuges for beneficial arthropods in farmland: longterm changes in predator communities and habitat. Agricultural and Forest Entomology, v. 6, p. 2, p. 147-154, 2004. https://doi. org/10.1111/j.1461-9563.2004.00215.x.

Panizzi, A.R.; Schaefer, C.W. Broad-headed bugs (Alydidae). In: Panizzi, A.R.; Grazia J. (Eds.). True bugs (Heteroptera) of the Neotropics. Entomology in Focus 2. Dordrecht: Springer, 2015. Chap 18, p. 537-549. https://doi.org/10.1007/978-94-017-9861-7_18.

Philpott, S.M. Biodiversity and pest control services. In: Levin, S.A. (Ed.). Encyclopedia of Biodiversity. 2.ed. Waltham: Academic Press, 2013. p. 373-385. https://doi.org/10.1016/B978-0-12384719-5.00344-0.

Rabinovich, J.E. Introducción a la ecologia de poblaciones animales. México: Continental, 1980. 313p.

Sappington, T.W.; Hesler, L.S.; Allen, K.C.; Luttrell, R.G.; Papiernik, S.K. Prevalence of sporadic insect pests of seedling corn and factors affecting risk of infestation. Journal of Integrated Pest Management, v. 9, n. 1, p. 1-27, 2018. https://doi.org/10.1093/ jipm/pmx020.

Schaefer, C.W.; Ahmad, I.A. Revision of Neomegalotomus (Hemiptera: Alydidae). Neotropical Entomology, v. 37, n. 1, p. 30-44, 2008. https://doi.org/10.1590/S1519-566X2008000100005.

Schwertner, C.F.; Nardi, C. Burrower bugs (Cydnidae). In: Panizzi A.R.; Grazia J. (Eds.). True bugs (Heteroptera) of the neotropics. Entomology in Focus 2. Dordrecht: Springer, 2015. Chap. 21, p. 639-680. https://doi.org/10.1007/978-94-017-9861-7_21. 
Sediyama, T.; Silva, F.; Borém, A. Soja do plantio à colheita. Viçosa: Editora UFV, 2015. 333p.

Smaniotto, L.; Panizzi, A.R. Interactions of selected species of stink bugs (Hemiptera: Heteroptera: Pentatomidae) from leguminous crops with plants in the Neotropics. The Florida Entomologist, v. 98, n. 1, p. 7-17, 2015. https://doi.org/10.1653/024.098.0103.
Ventura, M.U.; Panizzi, A.R. Population dynamic, gregarious behavior and oviposition preference of Neomegalotomus parvus (Westwood) (Hemiptera: Heteroptera: Alydidae). Brazilian Archives of Biology and Technology, v. 46, n. 1, p. 33-39, 2003. https://doi.org/10.1590/S151689132003000100006 